\title{
Ambidextrous Strategy and Firm Performance: The Moderating Effects of Organizational Slack and Organizational Life Cycle
}

\author{
Changyue Luo ${ }^{1}$, Dongli Zhang ${ }^{2}$, Biao Luo $^{3}$, Jiajia Ge $^{4}$ \\ ${ }^{1}$ Opus College of Business, University of St Thomas, 1000 Lasalle Ave, Minneapolis, MN, 55403, USA \\ ${ }^{2}$ Gabelli School of Business, Fordham University, 441 East Fordham Road Hughes Hall 510, New York, 10458, USA \\ ${ }^{3}$ School of Management, University of Science and Technology of China, 96 JinZhai Road, Hefei, Anhui Province, \\ 230026, China \\ ${ }^{4}$ School of Economics and Management, Yiwu Industrial \& Commercial College, 2 College Road, Yiwu, Zhejiang \\ Province, 322000, China
}

Correspondence: Dongli Zhang, Gabelli School of Business, Fordham University, 441 East Fordham Road Hughes Hall 510, New York, NY USA 10458, USA.

Received: June 12, 2017

Accepted: September 15, 2017

Online Published: September 24, 2017

doi:10.11114/bms.v3i4.2666

URL: https://doi.org/10.11114/bms.v3i4.2666

\begin{abstract}
The relationship between ambidexterity and firm performance holds a prominent place in the literature. However, studies that examine the conditions under which ambidexterity leads to success are relatively scarce. Based on a sample of 226 firms in China, this study examines the moderating effects of organizational slack and organizational life cycle on the relationship between balance dimension of ambidexterity and combined dimension of ambidexterity and firm performance. The empirical results reveal that pursuing a high level of combined dimension of organizational ambidexterity is only beneficial to firms with a high level of organizational slack or firms in maturity stage, while pursuing a high level of balance dimension of organizational ambidexterity is only beneficial to firms in growth stage, but not to firms in maturity stage.
\end{abstract}

Keywords: ambidexterity, combined dimension, balance dimension, organizational slack, organizational life cycle, survey

\section{Introduction}

This study investigates how different dimensions of ambidexterity of exploration/exploitation influence firm performance when considering the moderating effects of two different factors. In recent years, the concept of organizational ambidexterity has drawn an increasing attention of scholars (March 1991; Tushman, O’Reilly 1996; He, Wong 2004; Raisch et al., 2009). According to March (1991), exploration and exploitation are two basic forms of organizational learning and innovation strategy. Exploration involves searching for new knowledge, possibilities, and opportunities while exploitation pertains to the refinement of existing competencies and capabilities. Exploitation emphasizes the need for efficiency, consistency, customer-responsiveness, and reliable processes; while exploration focuses on dealing with changing environments, changing requirements, and innovation (O'Reilly, Tushman 2011; Benner, Tushman, 2003; He, Wong 2004). The way that organizations manage exploration-exploitation tension can be grouped into two streams: punctuated equilibrium and ambidexterity. Earlier researchers usually take the stream of punctuated equilibrium and argued that exploration and exploitation are incompatible with each other, with most firms having a tendency to adopt either an exploratory strategy or an exploitative strategy (Ghemawat, Ricart Costa 1993; March 1991). For example, when March (1991) first introduced the two learning activities of exploration and exploitation to the management literature, he argued that they should be viewed as two ends of a single continuum. In March's conceptualization, exploration and exploitation result in conflicting resources and organizational demands on the firm. More recently, researchers started to argue that organizations could do both of exploitation/exploration activities simultaneously. The ambidextrous argument states that firms engaging in both exploration and exploitation adapt better to changes in the environment and gain long-term survival (Benner, Tushman 2003; Gupta et al., 2006).

It is believed that the long-term success of an organization depends on its ability to exploit its current capabilities while at 
the same time explore new possibilities (Raisch et al., 2009). The increasing attention of ambidexterity requires scholars to investigate more thoroughly of the relationship between ambidexterity and firm performance. As Raisch et al. (2009) pointed out, further studies are needed to explore how different environmental and organizational factors impact the relationship between ambidexterity and performance outcome. In order to help organizations gain more from their ambidextrous strategy and effort, factors that may influence the performance impact of ambidexterity need to be identified and investigated. Following this research need, this study first differentiates two different dimensions of ambidexterity and explores if there are any direct relationships between each dimension of ambidexterity and performance. Then we identify certain factors that might moderate the relationships between the different forms of ambidexterity and performance. We propose a moderating role of organizational slack on the relationship between different dimensions of ambidexterity and performance. In the study, we examine how organizational slack releases the tension of competing for limited resources in implementing ambidextrous strategy. We also propose a moderating role of organizational life cycle on different forms of ambidexterity and performance.

This rest of the paper is organized as follows. Section 1 develops the theoretical model and presents the research hypotheses. Section 2 presents the empirical research settings of the study. Section 3 tests the hypotheses and shows the results. Section 4 discusses research implications, managerial implications, and limitations of this study.

\section{Theory Development}

\subsection{Ambidexterity of Exploration/Exploitation}

There are two components of organization's ambidextrous efforts: exploitation and exploration. Exploitative activities usually build on existing knowledge, which focuses on reinforcing the existing skills, processes, and structures. Exploitative activities are designed to meet the needs of existing customers or markets (Andriopoulos, Lewis 2009; Benner, Tushman 2003). On the contrary, exploratory activities depart from existing knowledge and are designed to meet the needs of emerging customers or markets through offering new designs, creating new markets, and developing new channels of distribution (Benner, Tushman 2003).

Recently, some scholars argued that firms' long-term survival and success depend on their ability to "engage in enough exploitation to ensure the firm's current viability and to engage in enough exploration to ensure future viability" (Benner, Tushman 2003; Gupta et al., 2006). Therefore, ambidexterity of exploration/exploitation draws an increasing attention of scholars. The concept of ambidexterity means that the firms are capable of both exploitative and exploratory activities simultaneously. Cao et al. (2009) studied two distinct but related dimensions of organizational ambidexterity, the balance dimension (BD) and the combined dimension (CD), and proposed that the two dimensions rely on different causal mechanisms to enhance firm performance. The balance dimension pertains to the balance between exploratory and exploitative effort, while the combined dimension pertains to the combined magnitude of the two types of activities.

A higher level of balance dimension (BD) of ambidexterity means that the firm maintains a close relative balance between exploration and exploitation, which contributes to firm performance through a better control of operating risk. A lower level of BD means an imbalanced effort between exploration and exploitation, which means the effort spent on one is significantly higher than the effort spent on the other. For example, firms could focus more on exploitative effort than exploratory effort. When this kind of imbalance happens, firms may face a higher risk of obsolescence. Firms may be benefit from exploiting existing technologies, current customers' needs, and current market needs short termly. However, the advantage might unable to be sustainable due to the changing environment, technologies, and market conditions. Therefore, performance might suffer in the long run(Leonard-Barton 1992), Conversely, if firms emphasize more on exploration and put very little effort of exploitation, the firms may have a higher risk of endless cycle of "search and unrewarding change" (Burgelman, Grove 2007). This will result in the incapability of the firms to exploit the fruits of their exploratory effort, which in term will hurt firm performance. In summary, a balance between exploitation and exploration should be required for organization ambidexterity. Implementing and achieving a closer balance of exploitation and exploration will benefit firms to gain more from their ambidextrous efforts.

Combined dimension of ambidexterity (CD), on the other hand, refers to the pursuit of a combined magnitude of both exploratory activities and exploitative activities. The central idea of CD is that exploratory and exploitative activities are not necessarily competitive with each other. On the contrary, the effort of one type of activities may help leverage the effects of the other. In other words, they may be supportive of each other and take place in complementary domains (Gupta et al., 2006).As Colbert (2004) argued, the pursuit of a CD strategy provides greater potential to develop and leverage complementary knowledge and resources between exploratory and exploitative efforts, thus facilitating firms to utilize both internal existing competencies and new emerging competencies. On the one hand, a high degree of exploitative effort can improve the firms' effectiveness in exploring new knowledge and new process. Exploitative effort of the current market and customers could also develop resources to support new products and markets. On the other hand, exploratory effort, such as acquiring new knowledge and developing resources that support new products and markets, 
can potentially facilitate application of routines and processes at a greater scale, where successful exploration can in turn improve the efficiency of existing exploitative endeavors. In summary, exploratory and exploitative activities can complement each other. A higher level of CD will lead to better firm performance by generating a greater pool of complementary resources that may be leveraged across both types of activities.

In summary, both the balance dimension and the combined dimension of ambidexterity are important to improve firm performance. We hypothesize that,

H1. The Balanced Dimension (BD) of ambidexterity is positively related to firm performance.

H2. The Combined Dimension (CD) of ambidexterity is positively related to firm performance.

\subsection{Organizational Slack and Its Moderating Effect on Ambidexterity and Performance}

Organizational lack refers to the type of resource in a firm that is in excess of what is required for the current efficient operation. Slack resources are needed since they can help firms buffer from internal uncertainty and environmental turbulences contestability (Bourgeois 1981; Tan, Peng 2003, Thompson 1967; Jansen et al., 2012). Depending on the degree of flexibility, slack resources can be categorized as unabsorbed slack and absorbed slack. Cash and raw material inventory are good examples of unabsorbed slack. Unabsorbed slack refers to those resources that are unused, readily available, and easily redeployed to various uses (Mishina et al., 2004). Owing to the relaxation of resource tensions, unabsorbed slack helps improving operational efficiency of current exploitative activities. Unabsorbed slack also relaxes firms' resource constraints and provides management flexible and unused resources to conduct exploratory activities, thus grasping emergent business opportunities in the environment, and ultimately improving firms' performance (Thompson 1967; Voss, Voss,. 2013).

Absorbed slack refers to those internal resources embedded in firms as excess costs, which has a lower degree of flexibility and cannot be reconfigured for various uses as easy as unabsorbed slack (Bourgeois 1981). Skilled labor and excess machine capacity are good examples of absorbed slack. On the one hand, absorbed slack provides firms with additional available resources to fuel exploitative activities and improve firm performance. On the other hand, as exploration usually requires firms to rapidly integrate internal and external resources and capabilities, it is difficult to allocate absorbed slack in the short run, due to its low degree of flexibility.

In this study, we use the construct of 'organizational slack' to capture both unabsorbed slack and absorbed slack. A higher level of organizational slack means a higher level of combined magnitude of both types of slack. A larger slack resource base enables firms to respond to potentially damaging risks associated with an unbalanced pursuit of exploration and exploitation in a more timely and effective manner (Csaszar 2013). A high level of BD can potentially mitigate the risk of obsolescence from over-committing to exploitation without a commensurate commitment to exploration, as well as the risk of failing to appropriate the fruits of exploration due to over-committing to exploration without a corresponding level of exploitation. When the firms have relatively lower level of organizational slack, a higher level of BD would be preferred. When the buffer of organization slack is missing in the organization, the firm needs to balance the exploitive and exploratory effort more carefully due to limited available resource. Therefore, we hypothesize that,

H3. Organizational slack moderates the relationship between BD and firm performance. High BD is more beneficial to firms with a low level of organizational slack.

Exploration and exploitation involve very different strategic goals, organizational structure design, and culture, therefore, they also demand different sets of organizational resources. Simultaneous enhancement of exploration and exploitation (CD) places a heavy demand on available resources (Csaszar 2013; Jansen et al., 2012; March 1991). As a consequence, when a firm possesses a larger stock of slack resources, high levels of exploratory and exploitative activities can be carried out more effectively (Knight, Harvey 2015), and the firm is more likely to benefit from pursuing a CD strategy. Firms with smaller stocks of slack resources will be constrained when try to provide sufficient resources to support CD strategy. Therefore, we hypothesize that,

H4. Organizational slack moderates the relationship between $\mathrm{CD}$ and firm performance. High CD is more beneficial to firms with a high level of organizational slack.

\subsection{Organizational Life Cycle and Its Moderating Effect on Ambidexterity and Performance}

Besides organizational slack, we also propose that there exists a difference in the choice of ambidexterity strategy between the firms at their different life cycle stage. Specifically, firms in growth stage are entering a period of rapid expansion. However, they usually have not accumulated abundant internal resources. In the meantime, firms in growth stage usually have a liability of newness (Freeman et al., 1983) which is difficult for firms in growth stage to obtain the necessary resources, such as financial capital, technology and information through strategic alliances and other ways from external channels. Facing such prominent resource constraints, growing firms may not be possible to mitigate the risks 
associated with the imbalance between exploration and exploitation, which ultimately impair the enterprise performance. Thus, pursing a high level of BD, or a closer match in the relative magnitude of exploratory and exploitative activities is more critical to firms in growth stage. On the contrast, firms in maturity stage usually have accumulated abundant internal resources. Thus, the risk associated the imbalance between exploration and exploitation is less threatening to firms in maturity stage. Therefore, we hypothesize that,

H5. Organizational life cycle influence the relationship between BD and firm performance. A high level of BD is beneficial to firms in growth stage but not firms in maturity stage.

Pursing high levels of exploration and exploitation simultaneously increases internal complexity and requires additional resources (Smith, Tushman2005). Firms in maturity stage who are larger and older likely have the resources, capabilities, and experience to successfully manage this complexity, whereas firms in growth stage may lack the necessary resources, capabilities, and experience to realize the benefits of CD. Moreover, contextual systems and processes represent another way to manage the internal complexity arising from simultaneous pursuit of high levels of exploration and exploitation (Gibson, Birkinshaw 2004; Voss, Voss 2013), this approach requires high-order meta-level capacities, including complex management systems and processes(Gibson, Birkinshaw 2004). However, it takes much time and experience to develop complex management systems (Van Looy et al., 2005; March 1991). Therefore, only firms stage have the ability to manage the internal complexity associated with $\mathrm{CD}$, hence carry out and benefit from $\mathrm{CD}$ more likely. Therefore, we hypothesize that,

H6. Organizational life cycle influence the relationship between CD and firm performance. A high level of CD is beneficial to firms in maturity stage but not firms in growth stage.

\section{Methodology}

\subsection{Sample and Data Collection}

A cross-sectional, survey-based research design was used to test the proposed conceptual model. The questionnaires were originally developed in English. Variables in our questionnaire are measured using already established instruments. Next, a conventional back-translation procedure was performed to avoid ambiguities and the potential for miscomprehension and ensure the accuracy of translation (Brislin 1970; Li, Atuahene-Gima 2001). First, a team member of this research project who is competent in both English and Chinese translated the questionnaire into Chinese. Next, another team member of this research project who is competent in both languages translated the Chinese version back into English. Translated versions were then compared carefully. The Chinese version was revised to avoid ambiguities and potential miscomprehension. To ensure the questionnaire was clear, relevant, and interpreted as expected, a pilot test was conducted with 25 firms. The questionnaire was revised based on the feedback from the pretest.

We delivered questionnaires to a total of 480 randomly selected firms from Database of Northeast Region Corporations maintained by the business school of University of Science and technology of China, including firms from Shanghai, Beijing, Zhejiang Province, Jiangsu Province and Anhui Province. Firms in China, a transitional economy, are facing a high degree of institutional and/or technological uncertain environment (Peng, Health 1996). The strategic choices made by these firms can potentially yield substantial variability in their degree of ambidexterity. Each of these firms was telephoned to establish contact with a manager (e.g., vice president of sales and marketing) who was knowledgeable about the survey issues and willing to participate. Reminder phone calls were made to encourage participation. Eight weeks after the initial mailing, 276 questionnaires were received, at which point the survey was closed. Removing 50 responses with incomplete data, a total of 226 valid questionnaires were obtained (for a response rate of $47.1 \%$ ). We summarize the basic characteristics of the sample firms in Table 1, including firm age, life cycle, ownership type, number of employees, and industry. 
Table 1. Basic Characteristics of Sample Firms

\begin{tabular}{|c|c|c|c|c|c|}
\hline & Sample Size & Percentage & Basic & Sample Size & Percentage \\
\hline Firm age & & & Number of employees & & \\
\hline less than 5 years & 31 & $13.7 \%$ & less than 50 & 29 & $12.8 \%$ \\
\hline 6 to 10 years & 60 & $26.5 \%$ & 50 to 100 & 33 & $14.6 \%$ \\
\hline 11 to 15 years & 40 & $17.7 \%$ & 100 to 500 & 48 & $21.2 \%$ \\
\hline more than 15 years & 95 & $42.1 \%$ & 500 to 1000 & 42 & $18.6 \%$ \\
\hline Life cycle & & & more than 1000 & 84 & $32.8 \%$ \\
\hline start-up stage & 12 & $5.3 \%$ & Industry & & \\
\hline growth stage & 135 & $59.7 \%$ & high-tech & 52 & $23.0 \%$ \\
\hline maturity stage & 79 & $35.0 \%$ & traditional manufacturing & 25 & $11.1 \%$ \\
\hline Ownership type & & & real estate & 29 & $12.8 \%$ \\
\hline state-owned & 76 & $33.6 \%$ & Trade & 32 & $14.2 \%$ \\
\hline private-owned & 111 & $49.1 \%$ & financial & 34 & $15.0 \%$ \\
\hline foreign-owned & 18 & $8.0 \%$ & machinery & 22 & $9.7 \%$ \\
\hline Others & 21 & $9.3 \%$ & others & 32 & $14.2 \%$ \\
\hline
\end{tabular}

3.2 Measures

Firm performance. Because the small to medium sized firms in our sample are not subject to the disclosure requirements of publicly traded companies, objective third-party data on their performance are not available. This study relied on key informants to provide subjective evaluation (Chandler, Hanks, 1993). To measure firm performance, we adapted the scale of $\mathrm{Wu}(2010)$ and measure firm performance over the last 12 months, on a 1-5 Likert scale, in terms of sales growth rate, return on assets (ROA), and profit ratio. The Cronbach's alpha of this scale is 0.886 .

Exploration and Exploitation. Organizational ambidexterity is an integrative construct of exploration and exploitation. Therefore, we measure BD and CD based on underlying measures of exploitation and exploration (He, Wong 2004; Cao et al., 2009). We adopted the scales of exploration and exploitation by Jansen et al. (2006) and He and Wong (2004), which proved to have high reliability by other studies (e.g. Cao et al., 2009; Lubatkin et al., 2006). The Cronbach's alpha for the exploration measure is 0.785 , and 0.807 for exploitation.

Balanced dimension of ambidexterity. As described earlier, BD refers to relative magnitudes of exploration and exploitation. We operationalize BD as the absolute difference between exploration and exploitation (He, Wong 2004; Cao et al., 2009). To facilitate interpretation, we reverse this measure by subtracting the difference score from 5 so that a higher value indicates greater $\mathrm{BD}$ :

$$
\mathrm{BD}=5 \text {-| Exploration - Exploitation | }
$$

Combined dimension of ambidexterity. As described earlier, $\mathrm{CD}$ relates to a firm's combined magnitude of exploration and exploitation. To reflect the theoretical proposition that high levels of exploration and exploitation can complement and enhance the other's impacts on performance, we operationalize CD as the product value of exploration and exploitation:

$$
\text { CD = Exploration * Exploitation (He, Wong 2004; Cao et al., 2009). }
$$

Organizational slack. Organizational slack is measured following prior studies by Nohria and Gulati (1996) and Tan and Peng (2003). The Cronbach's alpha for the organizational slack measure is 0.696.

Organizational Life Cycle. Organizational life cycle in this study was categorized into three stages: $1=$ start-up stage, $2=$ growth stage, and 3 = maturity stage.

Control variables. This study controls for the following factors: firm age, firm size, the property ownership of the firm, and industry type in the estimated models.

Table 2 shows the factor analysis of the constructs. As shown in Table 2, the Cronbach alpha coefficient values of all the variables are above the 0.6 (Gefen et al., 2000; Lin 2007). All factor loadings are greater than the cut-off point of 0.50 (Hair et al., 2005). Further, a principal component analysis rotated with Varimax was applied to the scale data of exploration, exploitation, organization slack, and firm performance. All Kaiser-Meyer-Oklin (KMO) values are greater than the recommended acceptable level of 0.6 (Fornell, Larcker 1981). 
Table 2. Factor Analysis of variables

\begin{tabular}{|c|c|c|c|c|}
\hline Variables & Items & Loading & $\begin{array}{l}\text { Cronbach's } \\
\text { a }\end{array}$ & $\mathrm{KMO}$ \\
\hline \multirow[t]{4}{*}{ Exploration } & $\begin{array}{l}\text { we are regularly committed to seek for new and potential } \\
\text { technologies }\end{array}$ & 0.702 & \multirow[t]{4}{*}{0.785} & \multirow[t]{4}{*}{0.764} \\
\hline & we are always willing to invent new products and services & 0.828 & & \\
\hline & $\begin{array}{l}\text { We commercialize products and services that are completely new to } \\
\text { our unit }\end{array}$ & 0.843 & & \\
\hline & $\begin{array}{l}\text { we regularly search for new markets and grasp new opportunities in } \\
\text { new markets }\end{array}$ & 0.788 & & \\
\hline \multirow[t]{4}{*}{ Exploitation } & $\begin{array}{l}\text { we are frequently committed to refine the quality of existing } \\
\text { products and services }\end{array}$ & 0.804 & \multirow[t]{4}{*}{0.807} & \multirow[t]{4}{*}{0.773} \\
\hline & $\begin{array}{l}\text { we are regularly committed to improve the production efficiency to } \\
\text { reduce costs }\end{array}$ & 0.763 & & \\
\hline & we are regularly committed to expand services for existing clients & 0.864 & & \\
\hline & we always try our best to keep and even expand the existing markets & 0.857 & & \\
\hline \multirow[t]{3}{*}{$\begin{array}{l}\text { firm } \\
\text { performance }\end{array}$} & $\begin{array}{l}\text { Compared with our major competitors, our sales growth rate is } \\
\text { better in last three years }\end{array}$ & 0.894 & \multirow[t]{3}{*}{0.886} & \multirow[t]{3}{*}{0.734} \\
\hline & $\begin{array}{l}\text { Compared with our major competitors, our return on assets(ROA) is } \\
\text { better in last three years }\end{array}$ & 0.923 & & \\
\hline & $\begin{array}{l}\text { Compared with our major competitors, our profit ratio is better in } \\
\text { last three years }\end{array}$ & 0.878 & & \\
\hline \multirow{6}{*}{$\begin{array}{l}\text { organizational } \\
\text { slack }\end{array}$} & We always have free cash flow for managers to allocate & 0.763 & \multirow[t]{6}{*}{0.696} & \multirow[t]{6}{*}{0.678} \\
\hline & $\begin{array}{l}\text { We always have enough retained earnings to satisfy the needs of } \\
\text { product development or market expansion }\end{array}$ & 0.751 & & \\
\hline & We always possess a lot of relation resources to utilize & 0.683 & & \\
\hline & $\begin{array}{l}\text { We always have access to loans from banks or other financial } \\
\text { institutions }\end{array}$ & 0.623 & & \\
\hline & $\begin{array}{l}\text { the process equipments and technologies of our firm are advanced } \\
\text { whose potential value has not been fully utilized }\end{array}$ & 0.594 & & \\
\hline & $\begin{array}{l}\text { We have many professional talents whose potential can be deeply } \\
\text { explored }\end{array}$ & 0.688 & & \\
\hline
\end{tabular}

Further, results of confirmatory factor analysis are summarized in Table 3.

Table 3. CFA Analysis

\begin{tabular}{lllllll}
\hline & $\mathrm{Chi}^{2} / \mathrm{df}$ & RMSEA & CFI & NFI & GFI & IFI \\
\hline Exploration & $4.512 / 2=2.08$ & 0.069 & 0.992 & 0.984 & 0.991 & 0.992 \\
Exploitation & $5.215 / 2=2.61$ & 0.085 & 0.989 & 0.982 & 0.989 & 0.989 \\
Organizational slack & $69.411 / 20=3.47$ & 0.095 & 0.791 & 0.737 & 0.930 & 0.798 \\
\hline
\end{tabular}

\section{Analysis and Empirical Results}

Table 4 reports the descriptive statistics and correlations of the variables. All inter-factor correlations are under the 0.65 threshold, which suggests that the estimations are not likely to be biased by multicollinearity problems (Tabachnick, Fidell 1996). The correlation between BD and CD is not significant with a value of 0.458 , which indicates preliminarily that $\mathrm{CD}$ and $\mathrm{BD}$ are two distinct dimensions of organizational ambidexterity.

Table 4. Descriptive Statistics and Correlation Matrix

\begin{tabular}{lllllllll}
\hline Var. & Mean & Std. & Explore & Exploit & Slack & Performance & BD & CD \\
\hline Explore & 3.88 & .76 & 1 & & & & & \\
Exploit & 4.13 & .68 & .615 & 1 & & & & \\
Slack & 3.77 & .63 & .381 & .427 & 1 & & & \\
Performance & 3.70 & .88 & .436 & .460 & .371 & 1 & 1 & \\
BD & 4.33 & .70 & .601 & .136 & .086 & .122 & .458 & 1 \\
CD & 16.36 & 4.82 & .618 & .549 & .440 & .490 & .458 \\
\hline
\end{tabular}

Note. $* \mathrm{p}<0005 ; * * \mathrm{p}<0001 ; * * * \mathrm{p}<0.0001$

To test our hypotheses, we employ hierarchical linear modeling (Bryk, Raudenbush 1992). All variance inflation factor values are less than the recommended cutoff point at 10, suggesting minimal likelihood of multicollinearity problems (Kleinbaum, Kupper and Muller 1988). Table 5 reports these regression results. 
Table 5. Test of Hypotheses

\begin{tabular}{llllll}
\hline \multirow{2}{*}{ Variables } & \multicolumn{5}{c}{ Dependent variable: Firm performance } \\
\cline { 2 - 6 } & Model 1 & Model 2 & Model 3 & $\begin{array}{l}\text { Model 4. } \\
\text { Growth Stage }\end{array}$ & $\begin{array}{l}\text { Model 5 } \\
\text { Maturity Stage }\end{array}$ \\
\hline Constant & 0.472 & 1.025 & -0.633 & 0.879 & $2.408^{*}$ \\
Age & -0.064 & -0.060 & -0.061 & $-0.127^{*}$ & -0.129 \\
Size & -0.055 & -0.004 & -0.007 & $0.036^{*}$ & -0.092 \\
Ownership & 0.060 & 0.058 & 0.063 & 0.045 & 0.101 \\
Industry & 0.010 & 0.010 & 0.010 & -0.023 & 0.028 \\
Slack & 0.265 & $0.253^{* * *}$ & 0.409 & $0.339^{* * * *}$ & -0.191 \\
Explore & 0.240 & 0.261 & $0.561^{*}$ & $0.294^{* * *}$ & $0.136^{* *}$ \\
Exploit & 0.326 & 0.233 & $0.504^{*}$ & $0.212^{*}$ & -0.151 \\
BD & & -0.112 & 0.473 & $0.023^{* * *}$ & $0.101^{* *}$ \\
CD & & 0.016 & -0.183 & $-0.019^{* * *}$ & \\
BD*slack & & & -0.160 & & 0.427 \\
CD*slack & & & $0.034^{* *}$ & & 0.352 \\
$\quad \mathrm{R}^{2}$ & 0.288 & 0.292 & 0.304 & 0.249 & \\
Adj_R $\mathrm{R}^{2}$ & 0.265 & 0.263 & 0.269 & 0.195 & 79 \\
$\Delta \mathrm{R}^{2}$ & & $0.004^{* * *}$ & $0.012^{* *}$ & & \\
$\mathrm{~N}$ & 226 & 226 & 226 & 135 & \\
\hline
\end{tabular}

Note. ${ }^{*} \mathrm{p}<0005 ; * * \mathrm{p}<0001 ; * * * \mathrm{p}<0.0001$

Model 1 is the base model that includes control variables, moderating variables, exploration, and exploitation. In Model 2, independent variables BD and CD are added. The results of Model 2 indicate that the balanced dimension of ambidexterity (BD) and firm performance is negatively correlated but not significant $(b=-0.112, p>0.1)$; the combined dimension of ambidexterity (CD) and firm performance is positively correlated, but also not significant $(b=0.016, p>$ 0.1). Therefore, hypothesis 1 and hypothesis 2 are not supported. We do not find direct relationships between the two dimensions of ambidexterity and firm performance. In Model 3, we further added the interaction terms BD*slack and CD*slack to Model 2. The results from Model 3 show that the interaction of BD and organizational slack has a negative impact on firm performance, but not significant $(b=-0.160, p>0.1)$. Thus, hypothesis 3 is not supported. The interaction of $\mathrm{CD}$ and organizational slack has a significant positive effect on firm performance $(b=0.034, \mathrm{p}<0.05)$. Therefore, $\mathrm{H} 4$ is supported.

Model 5 and Model 6 test the moderating effects of the organizational life cycle on the relationship between both dimensions of ambidexterity and firm performance. Considering that our independent variable and moderating variable are continuous variable and category variable, the sample is divided according to the value of the moderating variable (Little, Card, Bovaird, Preacher, and Crandall 2007). The moderating effect is tested by determining whether the difference is significant between the interaction terms of the independent variable and moderating variables in different sample groups. In this study, we divided the sample into growth stage (Model 5) and maturity stage (Model 6). The results in Model 5 show that BD has a significantly positive correlation with firm performance for firms in growth stage $(b=$ $0.023, \mathrm{p}<0.05)$. The results in Model 6 show an insignificant relationship between BD and firm performance for firms are in maturity stage. The distinctive results from Model 5 and Model 6 indicate that implementing BD strategy, i.e., keeping the balance of exploration and exploitation, is more beneficial to firms in growth stage rather than firms in maturity stage. Therefore, hypothesis 5 is supported. Furthermore, CD is found to be significantly negatively correlated with firm performance in Model $5(b=-0.019, p<0.01)$, while $C D$ and firm performance is significantly positively correlated in Model $6(b=0.101, p<0.05)$. We conclude that implementation of CD, i.e., the simultaneous pursuit of high levels of exploration and exploitation, is more beneficial to firms in maturity stage than to firms in growth stage. Hypothesis 6 is thus supported.

In summary, the empirical finding provides strong support for the hypothesized moderating effects of organizational slack and organizational life cycle. Figure 1 gives the conditional effect plot for firm performance as a function of CD conditioned on organizational slack. Figure 2 shows the conditional effect plot for firm performance as a function of BD conditioned on organizational life cycle. While Figure 3 gives the conditional effect plot for firm performance as a function of $\mathrm{CD}$ conditioned on organizational life cycle. 


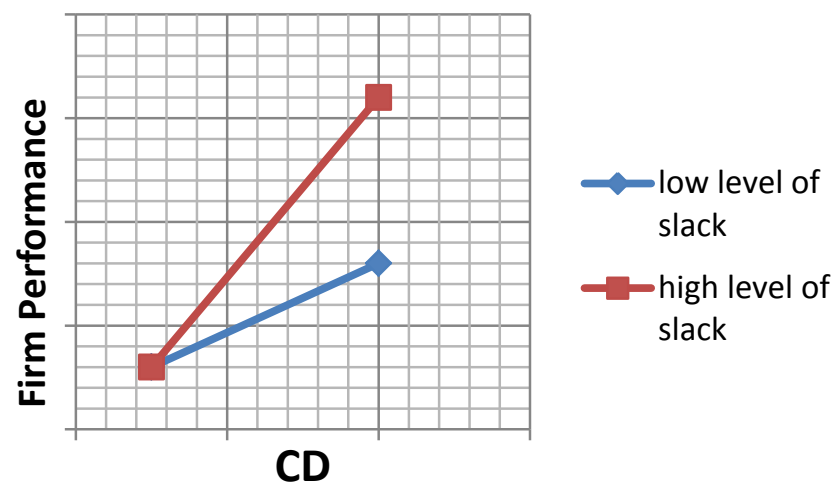

Figure 1. The Moderating Effect of Organizational Slack on the Relationship between CD and Performance

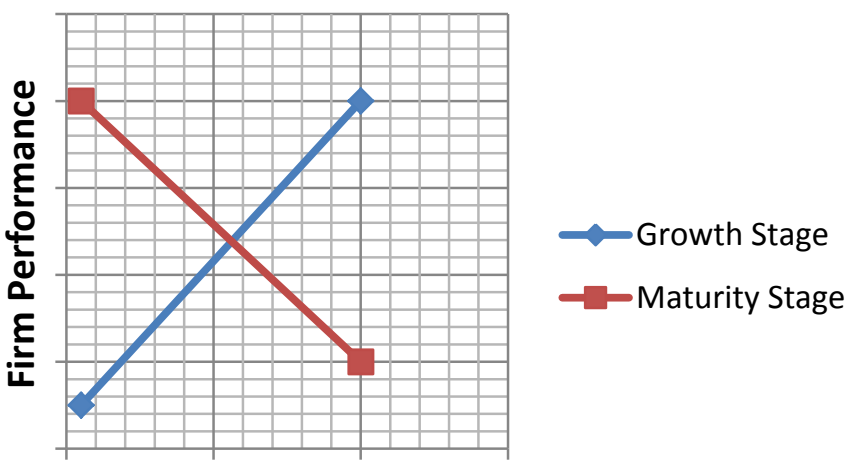

BD

Figure 2. The Moderating Effect of Organizational Life Cycle on the Relationship between BD and Performance

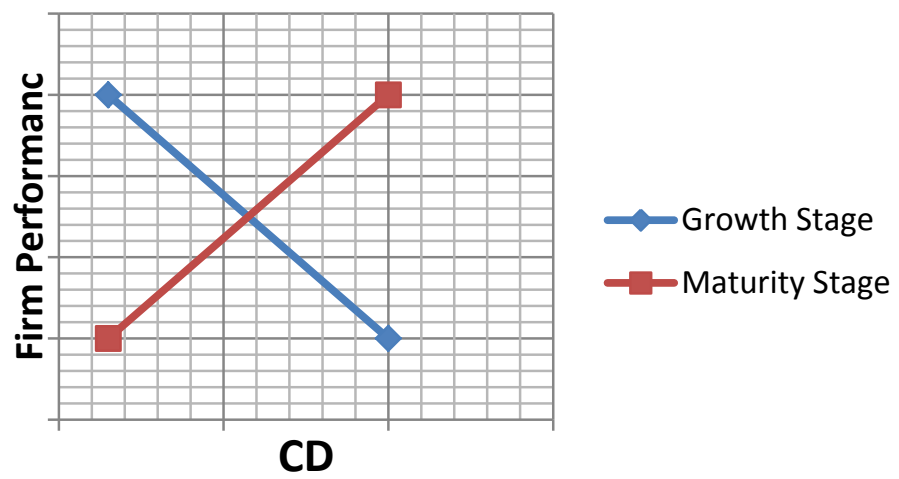

Figure 3. The Moderating Effect of Organizational Life Cycle on the Relationship between CD and Performance

The conditional effect plots show the moderating effect more straightforward. For example, in Figure 1, both lines show positive relationships between $\mathrm{CD}$ and firm performance. However, the slope of high level of slack is greater than the slope of firms with low level of slack. The result means that CD contributes to firm performance more when the firms have higher level of slack resources compared to the firms with lower level of slack resources. Figure 2 shows that BD contributes to firm performance only when organizations are at their growth stage. Figure 3 shows a different story, that $\mathrm{CD}$ contributes to firm performance only when organizations are in maturity stage. The conditional effect plots show 
clearly that when investigating how different dimensions of ambidexterity affect performance, moderating effects of different factors need to be taken into consideration.

\section{Discussion and Conclusions}

\subsection{Implications for Research}

This study is designed to examine the impacts of ambidexterity of exploration/exploitation on firm performance when considering the moderating effects of two different factors: organizational slack and organizational life cycle. Our empirical results provide interesting insights to the theoretical relationships we have hypothesized.

First, the empirical results do not support direct relationships between BD and firm performance, as well as CD and firm performance. However, when moderators are added in the models, we see interesting results of the hypothesized relationships. The moderating effects of organization slack and organizational life cycle on the relationships between ambidexterity and firm performance are strongly supported. When the direct links are missing in the relationships, it becomes more important and helpful to investigate the moderating effects of different contextual factors.

The main findings of this study are the moderating effects of organizational slack and organizational life cycle. Ambidexterity can only show the effect on performance when organizational slack or organizational life cycle is introduced into the model. The findings contribute to both the research on ambidexterity and the research on organizational slack and organizational life cycle. When examining the impact of ambidexterity, moderators need to be taken into consideration. The different impacts of organizational slack and organizational life cycle on BD and CD shows that scholars need to identify potential moderators in order to study the impact of ambidexterity on performance.

The empirical results suggest that the two dimensions of ambidexterity, balance dimension and combined dimension, contribute to firm performance through different mechanisms. First, when slack resources are relatively abundant, a higher level of combined magnitude of exploitation/exploration will benefit firm performance. However, the moderating effect of organizational slack is not significant on the relationship between a balanced effort of exploitation/exploration and firm performance. Furthermore, a more balanced effort of exploitation/exploration contributes to firm performance more only when the firms are in growth stage, while a higher level of combined magnitude of exploitation/exploration contributes to firm performance more for organizations in maturity stage.

\subsection{Managerial Implications}

This study offers several managerial implications. First, the study finds missing links between the two dimensions of ambidexterity and firm performance. Therefore, is it safe to say that firms could survive and grow without any forms of ambidexterity of exploration/exploitation efforts? The answer is no. In fact, the missing direct links suggest that when firms try to explore and exploit simultaneously, they need to consider certain contextual factors in order to gain more from their ambidextrous efforts. In other words, their exploitative/exploratory efforts will impact the performance differently under different contextual conditions. Second, identifying the moderating effect of organizational slack and organizational life cycle on the relationship between ambidexterity and performance provides guidance for organizations to achieve expected results from ambidextrous efforts. A sufficient level of slack resources will release the resource constraints within firms and thus mitigate the conflicts between exploration and exploitation, which will stimulate the synergy effects of exploratory and exploitative activities. When the organizational slack is sufficient, organizations could pursuit a higher level of combined magnitude of exploitation and exploration effects and get more performance benefits. Firms also need to check their life cycle stage in order to get more benefits from ambidexterity efforts. For firms in growth stage, a balanced effort of exploitation/exploration should be focused more in order to improve performance to a greater degree. On the contrary, for firms in maturity stage, the combined dimension of ambidexterity shows more significant relationship with firm performance. Firms need to check the combined magnitude of exploitation/exploration in order to achieve better performance in maturity stage.

\subsection{Limitations and Future Research}

This study is subject to certain limitations, which also suggest directions for future research. First, the sample of this study came from Northeast regions of China. This limits the generalizability of the research results. We suggest that further research could consider collecting data from more regions and countries and see if the relationships in this study still hold. Second, this study shows no support for the direct relationships between the two dimensions of ambidexterity and firm performance. We could only see the effects of ambidexterity on performance when we put the organizational slack and organizational life cycle as the moderators in the model. This shows a promising future research direction. More potential factors that may have a mediating or moderating effect on ambidexterity of exploitation/exploration and performance should be identified and empirically tested. More research on potential mediators or moderators will also benefit practitioners and provide more guidance for their ambidextrous efforts. 


\section{Funding}

This research was supported by National Natural Science Foundation of China under Grant 71272064 and Grant 71121061; and Technological Fund of Anhui Province for Outstanding Youth under Grant 1308085JGD07.

\section{References}

Andriopoulos, C., \& Lewis, M. W. (2009). Exploitation-Exploration Tensions and Organizational Ambidexterity: Managing Paradoxes of Innovation, Organization Science, 20(4), 696-717. https://doi.org/10.1287/orsc.1080.0406

Benner, M. J., \& Tushman, M. L. (2003). Exploitation, Exploration and Process Management: The Productivity Dilemma Revisited, Academy of Management Review, 28(2), 238-256.

Bourgeois, L. J. (1981). On the Measurement of Organizational Slack. Academy of Management Review, 6(1), 29-39.

Brislin, R. W. (1970). Back-Translation for Cross-Cultural Research. Journal of Cross-Cultural Psychology, September 1(3), 185-216. https://doi.org/10.1177/135910457000100301

Bryk, A., \& Raudenbush, S. W. (1992). Hierarchical Linear Models for Social and Behavioral Research: Applications and Data Analysis Methods. Newbury Park, CA: Sage.

Burgelman, R. A., \& Grove, A. S. (2007). Let Chaos Reign, then Rein in Chaos - Repeatedly: Managing Strategic Dynamics for Corporate Longevity. Strategic Management Journal, 28, 965-979. https://doi.org/10.1002/smj.625

Cao, Q., Gedajlovic, E., \& Zhang, H. (2009). Unpacking Organizational Ambidexterity: Dimensions, Contingencies, and Synergistic Effects. Organizational Science, 20(4), 781-796. https://doi.org/10.1287/orsc.1090.0426

Chandler, G. N., \& Hanks, S. H. (1993). Measuring the Performance of Emerging Businesses: A Validation Study. Journal of Business Venturing, 8(5), 391-408. https://doi.org/10.1016/0883-9026(93)90021-V

Colbert, B. A. (2004). The Complex Resource-based View: Implications for Theory and Practice in Strategic Human Resource Management. Academy of Management Review, 29(3), 341-358.

Csaszar, F. A. (2013). An Efficient Frontier in Organization Design: Organizational Structure as a Determinant of Exploration and Exploitation. Organization Science, 24(4), 1083-1101. https://doi.org/10.1287/orsc.1120.0784

Fornell, C., \& Larcker, D. F. (1981). Evaluating Structural Equations with Unobservables Variables and Measurement Errors. Journal of Marketing Research, 18(2), 39-50. https://doi.org/10.2307/3151312

Freeman, J., Carroll, G. R., \& Hannan, M. T. (1983). The Liability of Newness: Age Dependence in Organizational Death Rates. American Sociological Review, 48(5), 692-710. https://doi.org/10.2307/2094928

Gefen, D., Straub, D. W., \& Boudreau, M. C. (2000). Structural Equation Modeling and Regression: Guidelines for Research Practice. Communications of the Association for Information Systems, 4(7), 1-70.

Ghemawat, P., \& Ricart Costa, J. E. I. (1993). The Organizational Tension between Static and Dynamic Efficiency. Strategic Management Journal, 14(Winter), 59-73. https://doi.org/10.1002/smj.4250141007

Gibson, C. B., \& Birkinshaw, J. (2004). The Antecedents, Consequences, and Mediating Role of Organizational Ambidexterity. Academy of Management Journal, 47(2), 209-226. https://doi.org/10.2307/20159573

Gupta, A. K., Smith, K. G., \& Shalley, C. E. (2006). The Interplay between Exploration and Exploitation. Academy of Management Journal, 49(4), 693 706.

He, Z. L., \& Wong, P. K. (2004). Exploration vs. Exploitation: An Empirical Test of the Ambidexterity Hypothesis. Organization Science, 15(4), 481-494. https://doi.org/10.1287/orsc.1040.0078

Jansen, J. P., Simsek, Z., \& Cao, Q. (2012). Ambidexterity and Performance in Multiunit Contexts: Cross-level Moderating Effects of Structural and Resource Attributes, Strategic Management Journal, 33(1), 1286-1303. https://doi.org/10.1002/smj.1977

Jansen, J. P., Van Den Bosch, F. A., \& Volberda, H. W. (2006). Exploratory Innovation, Exploitative Innovation and Performance: Effects of Organizational Antecedents and Environmental Moderators, Management Science, 52(6),1661-1674. https://doi.org/10.1287/mnsc.1060.0576

Joseph, F. H. Jr., William, C. B., Babin, R., \& Anderson, R. T. (2005). Multivariate Data Analysis. Prentice-Hall, Upper Saddle River, NJ.

Kleinbaum, D. G., Kupper, L. L., \& Muller K. E. (1988). Applied Regression Analysis and other Multivariate Method(2nd Ed.). PWS-Kent, Boston, MA.

Knight, E., \& Harvey, W. (2015). Managing exploration and exploitation paradoxes in creative organizations. 
Management Decision, 53(4), 809-827. https://doi.org/10.1108/MD-03-2014-0124

Leonard-Barton, D. A. (1992). Core Capabilities and Core Rigidities: A Paradox in Managing New Product. Strategic Management Journal, 13(S1), 111-125. https://doi.org/10.1002/smj.4250131009

Li, H. K., \& Atuahene, G. (2001). Product Innovation Strategy and the Performance of New Technology Ventures in China. Academy of Management Journal, 44, 1123-1134. https://doi.org/10.2307/3069392

Lin, J. Y. (2007). Multivariate Analysis: SPSS Operation and Application (2nd Ed.). Taipei City, Taiwan, ROC: Best-Wise Publishing Co., Ltd.

Little, T. D., Bovaird, J. A., Card, N. A., Preacher, K. J., \& Crandall, C. S. (2007). Structural Equation Modeling of Mediation and Moderation with Contextual Factors. In Modeling Contextual Effects Longitudinal Studies. Edited by Little, T .D., Bovaird, J. A., Card, N. A., Published by Lawrence Erlbaum Associates, Inc. Publishers. Mahwah, New Jersey.

Lubatkin, M. H., Simsek, Z., \& Ling, Y. (2006). Ambidexterity and Performance in Small to Medium-sized Firms: The Pivotal Role of Top Management Team Behavioral Integration. Journal of Management, 32(5), 646-672. https://doi.org/10.1177/0149206306290712

March, J. G. (1991). Exploration and Exploitation in Organizational Learning. Organization Science, 2(1), 71-87. https://doi.org/10.1287/orsc.2.1.71

Mishina, Y., Pollock, T. G., \& Porac, J. F. (2004). Are more resources always better for growth? Resource stickiness in market and product expansion. Strategic Management Journal, 25(12), 1179-1197. https://doi.org/10.1002/smj.424

Nohria, N., \& Gulati, R. (1996). Is slack good or bad for innovation? Academy of management Journal, 39(5), 1245-1264. https://doi.org/10.2307/256998

O'Reilly, C. A., \& Tushman, M. L. (2011). Organizational ambidexterity in action: How managers explore and exploit. California Management Review, 53(4), 5-22. https://doi.org/10.1525/cmr.2011.53.4.5

Peng, M. W., \& Peggy, S. H. (1996). The growth of the Firm in Planned Economies in Transition: Institutions, Organizations, and Strategic Choice. Academy of Management Review, 21,492-528.

Raisch, S., Birkinshaw, J., Probst, G., \& Tushman, M. L. (2009). Organizational Ambidexterity: Balancing Exploitation and Exploration for Sustained Performance. Organization Science, 20(4), 685-695. https://doi.org/10.1287/orsc.1090.0428

Smith, W. K., \& Tushman, M. L. (2005). Managing strategic contradictions: A top management model for managing innovation streams. Organization science, 16(5), 522-536. https://doi.org/10.1287/orsc.1050.0134

Tabachnick, B. G., \& Linda. S. F. (1996). Using Multivariate Statistics. Harper Collins College Publishers, New York.

Tan, J., \& Peng, M. W. (2003). Organizational Slack and Firm Performance during Economic Transitions: Two Studies from an Emerging Economy. Strategic Management Journal, 24(13), 1249-1263. https://doi.org/10.1002/smj.351

Thompson, J. D. (1967). Organization in Action, McGraw-Hill, New York, N.Y.

Tushman, M. L., \& O’Reilly, C. (1996). Ambidextrous Organizations: Managing Evolutionary and Revolutionary Change. California Management Review, 38(4), 8-30. https://doi.org/10.2307/41165852

Van Looy, B., Martens, T., \& Debackere, K. (2005). Organizing for continuous innovation: On the sustainability of ambidextrous organizations. Creativity and Innovation Management, 14(3), 208-221. https://doi.org/10.1111/j.1467-8691.2005.00341.x

Voss, G. B., \& Voss, Z. G. (2013). Strategic Ambidexterity in Small and Medium-Sized Enterprises: Implementing Exploration and Exploitation in Product and Market Domains. Organization Science, 24(5), 1459-1477. https://doi.org/10.1287/orsc.1120.0790

Wu, L. Y. (2010). Applicability of the Resource-based and Dynamic-capability Views under Environmental Volatility. Journal of Business Research, 63(1), 27-31. https://doi.org/10.1016/j.jbusres.2009.01.007

\section{Copyrights}

Copyright for this article is retained by the author(s), with first publication rights granted to the journal.

This is an open-access article distributed under the terms and conditions of the Creative Commons Attribution license which permits unrestricted use, distribution, and reproduction in any medium, provided the original work is properly cited. 